\title{
OPTIMALISASI PEROKSIDASE DARI BUAH BELIMBING MANIS (Averrhoa carambola) UNTUK DEGRADASI SENYAWA FENOL
}

\author{
Ni Made Ratna Dwiyanthi ${ }^{1}$, Made Vivi Oviantari², I Putu Parwata ${ }^{3}$ \\ 1Jurusan Analis Kimia FMIPA Universitas Pendidikan Ganesha \\ 2Jurusan Analis Kimia FMIPA Universitas Pendidikan Ganesha \\ 3Jurusan Analis Kimia FMIPA Universitas Pendidikan Ganesha \\ e-mail: iputuparwata@gmail.com
}

\begin{abstract}
Abstrak
Tujuan dari penelitian ini untuk mengetahui $\mathrm{pH}$ dan suhu optimal yang diperlukan oleh ekstrak peroksidase dari buah belimbing manis dalam mengkatalisis reaksi degradasi senyawa fenol. Subjek penelitian ini adalah peroksidase yang diisolasi dari buah belimbing manis (Averrhoa carambola) yang sudah matang, sedangkan objek penelitian adalah $\mathrm{pH}$ dan suhu optimum yang diperlukan oleh peroksidase dari buah belimbing manis (Averrhoa carambola) untuk mendegradasi fenol. Peroksidase diekstraksi dari buah belimbing manis (Averrhoa carambola) yang sudah matang menggunakan blender dan disentrifugasi dengan kecepatan 5000 rpm selama 120 menit. Ekstrak enzim kemudian diuji aktivitasnya dalam mendegradasi fenol pada variasi $\mathrm{pH}$ dan suhu. Pengukuran konsentrasi fenol dilakukan dengan menggunakan spektrofotometer UV-Vis. Hasil penelitian menunjukkan bahwa degradasi senyawa fenol dengan biokatalisator peroksidase dari buah belimbing manis berlangsung optimum pada $\mathrm{pH} 5$ dan suhu $65^{\circ} \mathrm{C}$ dengan nilai efisiensi $72,71 \%$.
\end{abstract}

Kata kunci: peroksidase, buah belimbing manis, degradasi, fenol.

\begin{abstract}
The purpose of this study is to determine the optimum $\mathrm{pH}$ and temperature required by the peroxidase extracted from star fruit to catalyse the degradation of phenolic compound. The subjects of this study were the peroxidase that isolated from mature star fruit (Averrhoa carambola), while the objects were the optimum $\mathrm{pH}$ and temperature required by the enzyme to degrade phenol. Peroxidase were extracted from mature star fruit (Averrhoa carambola) using blender and then sentrifuge at $5000 \mathrm{rpm}$ for 120 minutes. The enzyme extract was then tested on degradation of phenol at the variation of $\mathrm{pH}$ and temperature. Measurement of phenol concentration was performed using UV-Vis spectrophotometer. The result showed that the optimum degradation of phenolic compound by peroxidase extracted from star fruit lasted at $\mathrm{pH} 5$ and temperature of $65^{\circ} \mathrm{C}$ with the efficiency of $72,71 \%$
\end{abstract}

Keywords: peroxidase, star fruit,degradation, phenol

\section{Pendahuluan}

Dewasa ini perkembangan industri di Indonesia cukup pesat. Perkembangan industri ini memberikan dampak positif dan dampak negatif bagi kehidupan manusia dan lingkungannya. Dampak negatifnya antara lain dihasilkannya produk samping berupa limbah padat dan cair yang berdampak terhadap makhluk hidup dan lingkungan sekitarnya. Limbah cair yang dihasilkan mengandung banyak senyawa organik yang berbahaya bagi tubuh. Salah satu senyawa organik yang terdapat pada limbah cair industri seperti industri tekstil, petrokimia, farmasi dan industri kimia yaitu senyawa fenol (Rocha dkk, 2007).

Limbah yang mengandung fenol dapat mempengaruhi ekosistem perairan dan melalui berbagai aktivitas manusia, fenol dapat terakumulasi dalam tubuh dan menyebabkan gangguan pencernaan, kerusakan otak, paru-paru, ginjal, hati, pankreas, dan limpa (Isyuniarto et al., 2005).

*Corresponding author. 
Konsentrasi fenol dalam limbah umumnya berada dalam kisaran 10 $3000 \mathrm{mg} / \mathrm{L}$ (Shetty et al., 2007), sedangkan keberadaan senyawa fenol di lingkungan perairan yang masih diangggap aman, sesuai dengan KEP No. 51/MENLH/ 10/1995 tentang baku mutu kadar beban pencemaran maksimum air limbah, yakni 0,5 - 1,0 $\mathrm{mg} / \mathrm{L}$. Selain itu, nilai ambang batas fenol dalam baku air minum adalah $0.002 \mathrm{mg} / \mathrm{L}$ seperti yang dinyatakan oleh Badan Pengendalian Dampak Lingkungan (Bapedal) (Slamet et al., 2005).

Beberapa penelitian menggunakan cara kimia dan fisika untuk menghilangkan fenol. Secara kimia misalnya menggunakan radiasi sinar ultraviolet, teknik ultrasonik dengan atau tanpa katalis penggunaan ozon, fotokatalisis, serta reaksi Fenton. Metode-metode tersebut memiliki kelemahan antara lain biaya yang tinggi, adanya senyawa sampingan yang bersifat toksik, dan proses mineralisasi yang tidak sempurna sehingga pengolahan yang dilakukan kurang efektif. Untuk itu perlu diterapkan suatu metode yang lebih efektif untuk mengatasi kekurangan dari metode tersebut.

Degradasi enzimatik dipercaya dapat mengolah limbah fenol dengan bekerja secara selektif terhadap substrat tertentu, tidak menghasilkan reaksi samping sehingga ramah lingkungan, memiliki laju reaksi yang tinggi, range $\mathrm{pH}$ yang luas dan prosesnya lebih mudah dikontrol (Handayani, 2008).

Enzim yang dapat digunakan sebagai biokatalis pada degradasi senyawa fenol adalah peroksidase. Peroksidase terdapat pada tumbuhan, hewan dan mikroba. Salah satu tumbuhan yang mengandung peroksidase adalah belimbing manis (Laurenti dan Clemente, 2010). Belimbing manis merupakan tanaman yang tumbuh subur di daerah tropis seperti Indonesia. Pemanfaatan buah belimbing sampai saat ini terbilang kurang efektif karena kurang diminati untuk konsumsi maupun pembuatan produk olahan lain. Untuk itu penelitian ini memanfaatkan ekstrak buah belimbing manis sebagai sumber peroksidase untuk mendegradasi senyawa fenol

Aktivitas enzim dipengaruhi oleh beberapa faktor, terutama $\mathrm{pH}$ dan suhu. Enzim bekerja secara optimal pada $\mathrm{pH}$ dan suhu tertentu. Di bawah atau di atas nilai optimum tersebut, kerja enzim akan menurun. Oleh karena itu, penelitian ini bertujuan untuk mengetahui $\mathrm{pH}$ dan suhu optimum yang diperlukan peroksidase dari buah belimbing manis (Averrhoa carambola) dalam mendegradasi fenol.

\section{Metode Penelitian Bahan}

Bahan yang digunakan dalam penelitian ini antara lain buah belimbing manis, $\mathrm{H}_{2} \mathrm{O}_{2}, \mathrm{NH}_{4} \mathrm{OH}$, fenol, 4aminoantipirin, larutan buffer universal $\mathrm{pH} 4 ; 5 ; 6 ; 7$ dan 8, kalium ferisianida $\left(\mathrm{K}_{3} \mathrm{Fe}(\mathrm{CN})_{6}\right)$, aquades, aluminium foil, wrapping plastic.

\section{Peralatan}

Peralatan yang digunakan dalam penelitian ini adalah spektrofotometer UV-Vis (Shimadzu UVmini-1240), sentrifuge (Thermo Sientific SL 16R), neraca analitik (Kern ABj), kaca arloji, botol sampel, corong, spatula, pipet tetes, batang pengaduk, gelas kimia 50 $\mathrm{mL}$ (Pyrex), labu ukur $50 \mathrm{~mL}, 100 \mathrm{~mL}$ dan $1000 \mathrm{~mL}$ (Herma), water bath (Memmert), Erlenmeyer $100 \mathrm{~mL}$ (Schott Duran), $\mathrm{pH}$ meter (Schott Instrument Lab 850), pipet volumetri, pipet ukur, blender, kasa, gelas ukur dan pipet mikro.

\section{Cara Kerja \\ Ekstraksi Peroksidase dari Buah Belimbing Manis}

Sebanyak $50 \mathrm{~g}$ buah belimbing dihomogenkan dalam $50 \mathrm{~mL}$ larutan buffer universal ( $\mathrm{pH}$ 7) pada suhu kamar, kemudian dihancurkan dengan blender agar didapatkan sari kasar. Homogenat disaring dengan kasa dan disentrifugasi dengan kecepatan 5000 rpm selama 120 menit. Hasil sentrifugasi dipisahkan dari endapannya menggunakan metode dekantasi. 
Supernatan yang diperoleh merupakan ekstrak enzim kasar (crude extract).

\section{Uji Degradasi Fenol pada Variasi pH dan Suhu}

Sebanyak $10 \mathrm{~mL}$ larutan fenol dengan konsentrasi 100 ppm dimasukkan ke dalam botol sampel. Preparasi larutan fenol $\mathrm{pH} 4$ dilakukan dengan penambahan larutan $\mathrm{HCl} 0,01$ $\mathrm{M}$, kemudian ditambah dengan $1 \mathrm{~mL}$ larutan buffer $\mathrm{pH} 4$ dan $10 \mathrm{~mL}$ larutan $\mathrm{H} 2 \mathrm{O} 2$. Campuran ditambahkan dengan 2,5 $\mathrm{mL}$ ekstrak enzim sehingga konsentrasi sampel menjadi $35 \mathrm{ppm}$, kemudian diinkubasi selama 5 jam pada suhu kamar. Untuk kontrol negatif, ekstrak enzim ditambahkan setelah inkubasi selama 5 jam pada suhu kamar. Kadar fenol hasil degradasi diukur menggunakan Spektrofotometer UV-Vis. Cara yang sama dilakukan untuk perombakan pada $\mathrm{pH} 5,6,7$, dan 8. Pengulangan dilakukan sebanyak dua kali. Variasi suhu menggunakan cara yang sama dengan $\mathrm{pH}$ optimum $(\mathrm{pH} \mathrm{6)}$ dan suhu inkubasi divariasikan, yaitu 55 , $60,65,70,75,80$, dan $85^{\circ} \mathrm{C}$.

\section{Hasil dan Pembahasan \\ Ekstraksi Peroksidase dari Buah Belimbing Manis}

Hasil ekstraksi enzim ditunjukkan pada Gambar 1. Berdasarkan Gambar 1. diketahui bahwa ekstrak kasar yang telah disentrifugasi tampak lebih bening dibandingkan dengan ekstrak sebelum disentrifugasi yang berwarna oranye pekat. Perubahan warna tersebut dikarenakan adanya pengendapan residu-residu yang tidak diinginkan selama proses sentrifugasi pada bagian dasar tabung. Supernatan dipisahkan dari endapannya dengan metode dekantasi.

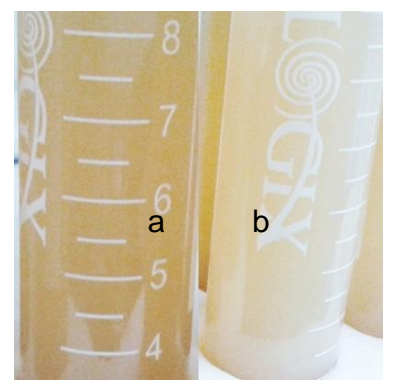

Gambar 1. Ekstrak Kasar Peroksidase Buah Belimbing Manis (a. Ekstrak Kasar Enzim Sebelum Sentrifugasi; b. Ekstrak Kasar Enzim Setelah Sentrifugasi)

Degradasi Fenol pada Variasi pH

Efisiensi degradasi fenol oleh ekstrak peroksidase buah belimbing manis pada variasi $\mathrm{pH}$ disajikan pada Gambar 2. Efisiensi degradasi fenol oleh peroksidase dipengaruhi oleh faktorfaktor lingkungan. Enzim dapat bekerja secara optimal dalam kondisi yang optimal pula. Salah satu kondisi lingkungan yang mempengaruhi kerja enzim adalah $\mathrm{pH}$. Enzim bekerja pada kisaran $\mathrm{pH}$ tertentu dan pada $\mathrm{pH}$ tersebut keadaan ionisasi yang tepat terjadi pada sisi aktif enzim sehingga pengikatan substrat berlangsung efektif pada kecepatan optimum (Sadikin, 2002). 


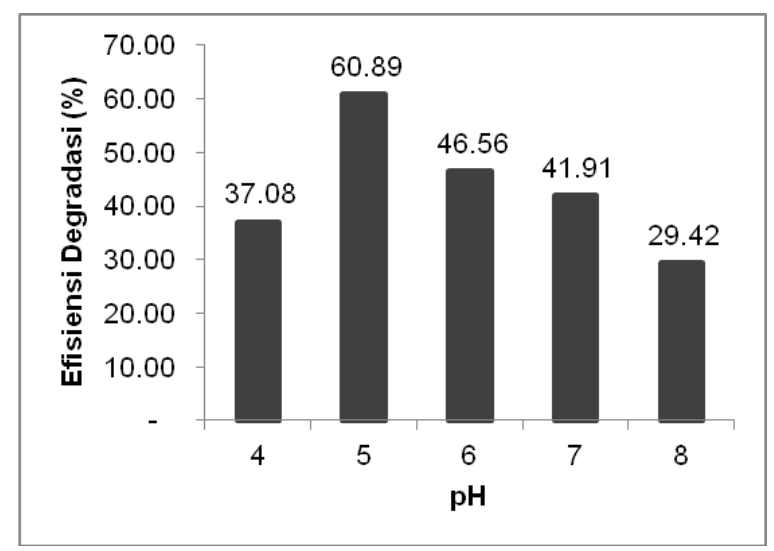

Gambar 2. Efisiensi Degradasi Fenol Oleh Peroksidase dari Buah Belimbing Manis pada Variasi $\mathrm{pH}$

Berdasarkan hasil penelitian, pada $\mathrm{pH} 4$ memiliki nilai efisiensi degradasi rendah, yaitu sebesar $37,08 \%$. Pada $\mathrm{pH}$ 5 terjadi peningkatan nilai efisiensi yang cukup tajam, yaitu dengan nilai efisiensi $60,89 \%$. Pada $\mathrm{pH} 6,7$, dan 8 nilai efisiensi berturut-turut menurun menjadi 46,56; 41,91; dan 29,42\%.

Pada $\mathrm{pH}$ yang asam, seperti $\mathrm{pH} 4$, aktivitas enzim menurun karena konsentrasi $\mathrm{H}^{+}$yang tinggi mempengaruhi muatan listrik enzim. Peroksidase merupakan enzim yang bersifat anion, sehingga mudah berikatan dengan $\mathrm{H}^{+}$. Pada kondisi yang terlalu asam, histidin akan terprotonasi oleh $\mathrm{H}^{+}$sehingga tidak dapat menerima proton dari peroksida (Azevedo dkk, 2003).

Pada pH 5 masih bersifat asam, namun bukan asam kuat. Pada $\mathrm{pH}$ ini, dengan konsentrasi ion $\mathrm{H}^{+}$yang lebih sedikit dibandingkan pada $\mathrm{pH} 4$, pengaruhnya terhadap muatan listrik enzim juga berkurang sehingga enzim dapat mengikat dan mengkatalisis substrat lebih banyak.

Pada pH 6 dan 7, efisiensi degradasi mengalami penurunan secara teratur, namun masih cukup tinggi. Dalam tingkat keasaman ini, peroksidase masih dapat bekerja dengan baik dalam mengkatalisis proses degradasi fenol. Pada $\mathrm{pH} 8$, terjadi penurunan efisiensi degradasi yang cukup tajam. Pada tingkat keasaman ini, enzim masih aktif bekerja mendegradasi fenol, namun degradasi terjadi dalam jumlah yang minimum.
Pada kondisi ini ion $\mathrm{OH}^{-}$terdapat dalam jumlah yang berlebih dalam lingkungan. Histidin akan mengikat atom $\mathrm{H}$ dari ion $\mathrm{OH}^{-}$dan besi heme mengikat atom $\mathrm{O}$ dari ion $\mathrm{OH}^{-}$.Akibat dari pengikatan tersebut, terjadi kompetisi antara ion $\mathrm{OH}^{-}$dengan substrat $\mathrm{H}_{2} \mathrm{O}_{2}$ pada sisi aktif enzim.

Berdasarkan hasil penelitian degradasi senyawa fenol menggunakan peroksidase dari buah belimbing manis, $\mathrm{pH}$ optimum yang didapatkan adalah $\mathrm{pH}$ 5. Hal ini sesuai dengan penelitian Laurenti dan Clemente (2010) mengenai karakteristik peroksidase dari buah belimbing manis yang memiliki rentang $\mathrm{pH}$ 4-7,5 sebagai rentang $\mathrm{pH}$ optimum. Penelitian (Handayani et al., 2008) dengan sumber peroksidase dari daun mangkokan mendapatkan $\mathrm{pH}$ optimum 7 dan penelitian oleh (Zulfahair et al., 2008) dengan sumber peroksidase dari kulit batang ubi kayu mendapatkan $\mathrm{pH}$ optimum untuk degradasi fenol yaitu $\mathrm{pH}$ 8. Perbedaan ini menunjukkan tingkat keasaman optimum peroksidase berbeda tergantung pada asal enzimnya (Hidayat, 1998).

\section{Degradasi Fenol pada Variasi Suhu}

Efisiensi degradasi fenol oleh ekstrak peroksidase buah belimbing manis pada variasi $\mathrm{pH}$ disajikan pada Gambar 4. Berdasarkan Gambar 4, pada suhu 55 dan $60^{\circ} \mathrm{C}$, nilai efisiensi degradasi masih rendah yakni dengan nilai berturut-turut sebesar $26,59 \%$ dan $26,19 \%$. Nilai efisiensi mencapai titik tertinggi pada suhu $65^{\circ} \mathrm{C}$ yakni sebesar 
$72,71 \%$. Pada suhu $70,75,80$, dan $85^{\circ} \mathrm{C}$, nilai efisiensi berturut-turut menurun dengan nilai $57,41 \%, 55,04$ $\%$, $46,58 \%$, dan $42,33 \%$.

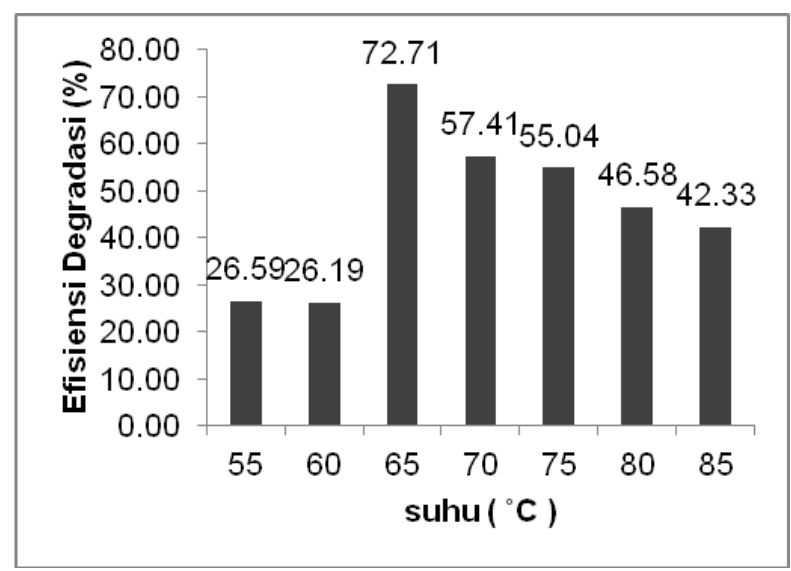

Gambar 4. Efisiensi Degradasi Fenol oleh Peroksidase Buah Belimbing Manis pada Variasi Suhu

Peroksidase merupakan enzim yang bersifat termofilik yaitu memiliki ketahanan terhadap suhu tinggi dan aktif pada suhu tersebut. Pada suhu 55 dan $60^{\circ} \mathrm{C}$, efisiensi degradasi cukup rendah. Pada suhu ini kinerja enzim berkurang, namun enzim tidak rusak hanya bentuknya masih kaku. Energi kinetik enzim dan substrat belum cukup untuk menyebabkan benturan pembentuk kompleks enzim-substrat (Zulfahair et al., 2008).

Kenaikan efisiensi degradasi hingga $46 \%$ terjadi pada suhu $65^{\circ} \mathrm{C}$. Efisiensi pada suhu ini merupakan efisiensi tertinggi dengan energi kinetik enzim dan substrat mencapai nilai optimum (Handayani et al., 2008). Pada suhu 70 hingga $85^{\circ} \mathrm{C}$, efisiensi enzim berkurang 15 sampai $30 \%$ dari suhu $65^{\circ} \mathrm{C}$. Nilai efisien dan aktivitas enzim pada suhu-suhu tersebut cenderung stabil. Pada suhu ini, enzim mengalami inaktivasi sebagian, walaupun tidak sepenuhnya karena masih terdapat aktivitas enzim. Penurunan aktivitas terjadi karena penurunan pembentukan kompleks karena energi kinetik yang tinggi tidak dapat menyatukan substrat dan enzim secara tepat (Handayani et al., 2008).

Rentang suhu optimal untuk peroksidase diperkirakan antara $60^{\circ} \mathrm{C}$ hingga $85^{\circ} \mathrm{C}$ (Laurenti \& Clemente,
2010). Pada penelitian ini suhu optimum degradasi fenol adalah $65^{\circ} \mathrm{C}$ Suhu ini merupakan batasan suhu tinggi yang dapat meningkatkan kerja peroksidase. Selain itu, peroksidase yang diperoleh dari eksrak buah belimbing manis ini juga menghasilkan aktivitas yang cukup baik pada rentang suhu yang cukup lebar yaitu $65-85^{\circ} \mathrm{C}$.

Suhu optimum yang tinggi yaitu $65^{\circ} \mathrm{C}$ menegaskan bahwa peroksidase merupakan golongan enzim termofilik. Hasil penelitian dari (Laurenti \& Clemente, 2010) yang melaporkan bahwa aktivitas peroksidase dari buah belimbing manis dipengaruhi oleh waktu dan suhu lingkungan, secara umum mengalami penurunan sekitar $85 \%$ dari aktivitas enzimnya setelah 10 menit perlakuan termal pada suhu $85^{\circ} \mathrm{C}$. Berdasarkan hasil penelitian yang diperoleh, penurunan aktivitas enzim pada suhu $85^{\circ} \mathrm{C}$ sekitar $58 \%$ dari aktivitas pada suhu optimal. Hal ini menunjukkan penelitian ini lebih unggul dibandingkan penelitian yang dilakukan oleh (Laurenti \& Clemente, 2010) dengan sumber enzim yang sama.

\section{Simpulan dan Saran}

Pada penelitian ini, degradasi senyawa fenol dengan biokatalisator peroksidase dari buah belimbing manis berlangsung optimum pada $\mathrm{pH} 5$ dan 
suhu $65^{\circ} \mathrm{C}$ dengan nilai efisiensi $72,71 \%$.

Peneliti yang berminat untuk melakukan penelitian sejenis dapat melakukan pemurnian enzim lebih lanjut dan dapat menambahkan variasi konsentrasi, waktu kontak serta perbandingan konsentrasi fenol dan $\mathrm{H}_{2} \mathrm{O}_{2}$.

\section{Daftar Pustaka}

Azevado, Ana M, Veronica C. Martins, Duarte M.F. Prazeres, Vojislav Vojinic, Joaquim M.S. Cabral dan Luis p. Fonsesa. 2003. Horseradish Peroxidase: A Valuable Tool in Biotechnology. Biotechnology Annual Review, Volume 9 (hlm 199-247)

Handayani, Santi Nur, Zulfahair dan Fofika Diah Rizaeni. 2008. Penggunaan Enzim Peroksidase dari Daun Mangkokan untuk Penurunan Kadar Fenol. Makalah disajikan dalam Seminar Nasional Aplikasi Sains dan Teknologi 2008. Universitas Negeri Jendral Soedirman. Purwokerto 13 Desember 2008.

Isyuniarto, Widdi Usada, Agus Purwadi dan Suryadi. 2005. Degradasi Fenol Dalam Limbah Pengolahan Minyak Bumi dengan Ozon. Yogyakarta : Pusat Penelitian dan Pengembangan Teknologi Maju. ISSN 76:02163128.

Laurenti, C and E. Clemente.2010. Some Properties of Peroxidase Extracted from Pulp of Star Fruit. Brazil : Laboratorio de Bioquimica de Alimentos.Brazil

Rocha LL, de Aquir Cordeiro R, Cavalcante RM, do Nascimento
RF, Martins SC, Santaella ST, dan Melo VM. 2007. Isolation and Characterization of Phenoldegrading Yeast from an Oil Refinery Wastewater in Brazil. Mycophatologia Volume 164 (hlm:183-188).

Sadikin, M. 2002. Biokimia Enzim. Jakarta : Widya Medika.

Shetty KV. Kalifathulla I, Srinikethan G. 2007. Performance of Pulsed Plate Bioreactor for Biodegradation of Phenol. J Hazard Mat Volume 140 (hlm:346352).

Slamet, R. Arbianti dan Daryanto. 2005. Pengolahan Limbah Organik (Fenol) dan Logam Berat (Cr6+atau Pt4+) secara Simultan dengan Fotokatalisis $\mathrm{TiO} 2, \mathrm{ZnO}-$ TiO2, dan CdS-TiO2. Makara Teknologi, Volume 9, No 2, November 2005. (hlm 66-71

Yohan, Hidayat. 1998. Pemanfaatan Peroksidase dari Lobak Sebagai Katalis Untuk Penanganan Limbah Fenol dengan Hidrogen Peroksida. SKRIPSI (tidak diterbitkan). Jurusan Kimia Universitas Diponegoro Semarang.

Zulfahair dan Santi Nur Handayani. 2008. Pemanfaatan Kulit Batang Ubi Kayu Sebagai Sumber Enzim Peroksidase Untuk Penurunan Kadar Fenol. Makalah disajikan dalam Seminar Nasional Aplikasi Sains dan Teknologi 2008. Universitas Negeri Jendral Soedirman. Purwokerto 13 Desember 2008. 